\title{
The NR4A nuclear receptor family in eosinophils
}

\author{
Ryoichi Hashida $\cdot$ Naganari Ohkura \\ Hirohisa Saito $\cdot$ Gozoh Tsujimoto
}

Received: 19 October 2006/ Accepted: 22 October 2006/ Published online: 10 November 2006

(C) The Japan Society of Human Genetics and Springer 2006

\begin{abstract}
It is well-known that many members of the family of nuclear receptors have been implicated in human diseases, and metabolic disorders in particular. The NR4A nuclear receptor family consists of three members, Nur77, Nurr1, and NOR1. All of these are orphan receptors, and Nur77 and NOR1 exert possible pathological roles in immune diseases through the modulation of leukocyte functions. CD30 stimulation, which induces eosinophil-specific apoptosis, markedly enhances expression of Nur77 and NOR1 in eosinophils. This suggests the possibility of pharmacological modulation of Nur77- or NOR1-specific apoptotic pathways via receptor-dependent transactivation. In this review, we discuss treatment of allergic diseases by low molecular weight compounds acting through the NR4A receptor family to cause eosinophil apoptosis. NR4A nuclear receptor genes were selected following comprehensive analysis of differentially expressed genes in eosinophils of atopic dermatitis patients compared with healthy volunteers.
\end{abstract}

R. Hashida $(\bowtie)$

Genox Research Inc., Bunkyo, Tokyo 112-8088, Japan

e-mail: hashiryo@mail1.accsnet.ne.jp

N. Ohkura

National Cancer Center Research Institute,

Chuo, Tokyo 104-0045, Japan

H. Saito

National Research Institute for Child Health and

Development, Setagaya, Tokyo 157-8535, Japan

G. Tsujimoto

Graduate School of Pharmaceutical Sciences,

Kyoto University, Sakyo, Kyoto 606-8501, Japan
Keywords Gene expression · Eosinophil ·

Atopic dermatitis - Apoptosis - NR4A nuclear receptor $\cdot$ NOR1 $\cdot$ Nur77 $\cdot$ Nurr1

\section{Nuclear receptors as pharmacological targets}

It has been reported that there are at most 400 molecular gene targets susceptible to pharmacological manipulation (Fauman et al. 2003), the majority of which have been identified as a result of classical drug development approaches. Almost all of those identified are enzymes and receptors. Following elucidation of the entire human genome, the percentage of enzyme and receptor genes qualifying as pharmacological target genes will be finite. These receptor genes consist of plasma membrane receptors (most of which are G-protein-coupled receptors; GPCRs) and nuclear receptors; the number of nuclear receptors in the entire human genome is reported to be 48 (Maglich et al. 2001). With regard to previous research directed at the identification of receptor ligands, the success rates in recognizing nuclear receptors as pharmacological target genes are considerably higher than in the case of GPCRs, of which several thousand exist in the human genome. Recent drug development strategies have been redirected towards the identification of gene targets before the identification of chemical structures, since all human genomic information is already available. In this context, nuclear receptors, about half of which are still orphan and whose endogenous ligands are as yet unknown, remain extremely attractive molecular targets for new medicines designed to treat a variety of diseases as well as metabolic disorders (Kliewer et al. 1999; Chawla et al. 2001). 


\section{Comprehensive gene expression analysis in eosinophils from patients with allergic diseases}

Both multigene interactions and environmental factors are likely to contribute to allergic diseases. Among infiltrating cells in pathologically diseased tissue, eosinophils in particular play causative roles in conditions such as asthma (Holt et al. 1999; Gleich 2000), atopic dermatitis (AD) (Kapp 1993; Leiferman 1994), and rhinitis (Gefand 2004; Eliashar and Levi-Schaffer 2005). Eosinophils are involved in tissue damage during the chronic phase of allergic diseases mediated by reactive oxygen species, lipid mediators, cytokines, and cytotoxic granular proteins such as major basic protein and eosinophil cationic protein (Bochner 2000). However, expression analysis and functional studies of disease-related genes in these cells have not been carried out systematically to date. This is because the study of gene expression in eosinophils presents some difficulties in that the percentage of these cells in healthy peripheral blood is very low (less than $3 \%$ ). In addition, no appropriate cell lines are available for further in vitro functional studies, other than leukemic cell lines such as Eol1 (Saito et al. 1985) and AML14.3D10 (Baumann and Paul 1998). Recent developments in the technology of gene expression analysis, such as differential display (DD) (Liang and Pardee 1992; Ito et al. 1994), DNA microarray (Schmidt-Weber et al. 2001; Granucci et al. 2001), and real-time RT-PCR (Lie and Petropoulos 1998; Kafert et al. 1999) make it possible to efficiently survey the expression of large numbers of genes in small amounts of clinical samples, and new data on eosinophil accumulation and actions in pathological conditions are being accumulated.

Using the techniques described above, we at Genox Research Inc. have established systems for directly analyzing the expression of various genes in clinical samples, such as fractionated peripheral blood (Ogawa et al. 2003) and skin biopsies (Ito et al. 2004; Ogawa et al. 2005) obtained from allergic patients. These studies have revealed some novel genes implicated in performing essential roles in the pathological conditions characteristic of allergic diseases (Matsumoto et al. 2002, 2004a; Heishi et al. 2002; Imai et al. 2002; Hashida et al. 2003; Nagata et al. 2003; Ogawa et al. 2004; Kagaya et al. 2005a). A successful example of this approach has been the identification of the nuclear receptor gene family whose enhanced expression in peripheral blood eosinophils correlated with the pathological condition of AD. We will discuss not only the pathological importance of these genes, but also the possibility that these nuclear receptors may constitute novel pharmacological targets in strategies used to develop anti-allergic drugs.

The distinguishing feature of comprehensive gene expression analysis using DD or GeneChip methods lies in the likelihood of finding unexpected novel genes. However, the disadvantage of such an approach is that it cannot be determined whether a given change in gene expression is a cause or an effect of the disease in question. In the case of diagnostic marker genes, this does not matter. However, functional analyses are necessary to clarify whether or not a particular gene is a genuinely important potential pharmacological target of the disease. For these purposes, new techniques such as gene knockout (KO) or gene overexpression at both the cellular level and in animal models are useful approaches for clarifying gene function and validating the importance of genes in disease etiology. The strategy used when validating NR4A nuclear receptor family genes as targets for pharmacological manipulation in the treatment of allergic diseases is outlined below.

\section{Nuclear receptors in eosinophils}

DD and subsequent GeneChip analysis comparing gene expression in diseased samples with expression in healthy samples has been effective in the identification of new druggable genes in allergic diseases. We picked up 24 genes among a total of more than 10,000 genes in GeneChip by comparing highly purified peripheral blood eosinophils of AD patient samples with those from healthy volunteers (Kagaya et al. 2005a). While there were no GPCRs among the 24, two nuclear receptors in the same NR4A orphan nuclear receptor family, Nur77 and NOR1, were identified. Using a larger number of samples, the expression of both receptor genes was measured by real-time RT-PCR. Nurr1, another member of the NR4A family, was not identified by GeneChip analysis. However, real-time RT-PCR demonstrated higher expression levels of Nurr1 in eosinophils from AD patients than in those from healthy volunteers. NOR1 had a particularly interesting expression profile, because it was the only receptor found to be eosinophil-specific among peripheral blood leukocyte fractions. Differences in NOR1 gene expression were also found by comparative DD analysis of eosinophils in the same patients during the exacerbation and remission phases of AD. NOR1 expression was remarkably elevated by bedside treatment, an effect accompanied by a dramatic decrease in the number of eosinophils in peripheral blood of these patients. 
It appears to be unprecedented that the presence of a nuclear receptor family correlates specifically with the pathology of an allergic disease. There are few reports of nuclear receptors in eosinophils, apart from a report by Ueki et al. (2003) of the presence of peroxisome proliferator-activated receptor gamma $(\operatorname{PPAR} \gamma)$. Recent evidence has suggested that PPAR $\gamma$ serves as a negative regulator in the immune system, while positively regulating adipogenesis and lipid metabolism in adipocytes (Forman et al. 1995; Kliewer et al. 1995). These authors provided interesting evidence that purified eosinophils express the nuclear receptor at mRNA and protein levels. Furthermore, the PPAR $\gamma$ agonist troglitazone inhibited IL5-stimulated (but not basal) eosinophil survival and eotaxin-directed chemotaxis. Inducing apoptosis of inflammatory cells through such specific nuclear receptors is an attractive approach and one which may constitute a goal in future treatment of allergic diseases. However, PPAR $\gamma$ expression and PPAR $\gamma$-mediated apoptosis are not eosinophil-specific; furthermore, PPAR $\gamma$ agonists are suggested to also act through distinct pathways other than PPAR $\gamma$ (Takeda et al. 2001). Therefore, the functions of this nuclear receptor need to be clarified further.

It is very suggestive that two among three family members were selected from more than 10,000 genes. All three NR4A nuclear receptor members are immediate-early genes which are poorly expressed under basic conditions in many tissues and cells, and induced within a few hours by various stimuli. NOR1 in particular is present at low copy number in nascent eosinophils, and expression levels increase rapidly on stimulation. Nevertheless, it could not be concluded from the clinical sample data alone whether expression of the NOR1 gene occurred as a cause or an effect; these receptors are thought to be related to regulation of eosinophil numbers in peripheral blood via apoptotic regulation of the cells.

\section{Apoptotic characteristics of the NR4A nuclear receptor}

Among the three genes (Nur77, Nurr1, and NOR1) which constitute the NR4A nuclear receptor family, Nur77 and Nurr1 have similar molecular biological characteristics, in that both receptors function as transcription factors forming heterodimers with retinoic X receptor (RXR) (Perlmann and Jansson 1995; Zetterstrom et al. 1996a; Vivat et al. 1997; Maira et al. 1999). They can mediate efficient transactivation through a DR-5 element in response to the RXR- specific ligand, 9-cis retinoic acid. On the other hand, the third member, NOR1, does not appear to interact with RXR, but functions as a homodimer or a monomer. Recently, Nurr1 has emerged as a possible target gene in Parkinson's disease (Kim et al. 2002), a condition known to be related to differentiation of dopaminergic neurons (Zetterstrom et al. 1996b; Saucedo-Cardenas et al. 1998); however, roles for Nurr1 in blood cells are almost unknown. On the contrary, there is evidence that Nur77 and NOR1 appear to function similarly in cells, because both molecules reportedly have apoptotic characteristics in immune cells (Cheng et al. 1997; Steff et al. 2001; He 2002; Winoto and Littman 2002). It follows that they may be implicated in disorders related to genetically or environmentally induced defects of activation-induced cell death (AICD), such as autoimmune diseases. Nur77 functions were firstly elucidated in $\mathrm{T}$ cells, where the gene is involved in CD3-induced cell apoptosis, or AICD signaling. Similarly, NOR1 was also found to be induced in $\mathrm{T}$ cells via the same signaling pathway.

The roles of this receptor family in eosinophil functions have not yet been clarified. CD30 stimulation has recently been shown to cause eosinophil-specific apoptosis (Matsumoto et al. 2004b). It has been further reported that CD30 stimulation markedly induced Nur77 and NOR1 during eosinophil-specific apoptosis (Kagaya et al. 2005a). However, CD30 stimulation did not alter Nurr1 expression in this system. Fas signaling has also been shown to induce eosinophil apoptosis, but this effect is not eosinophil-specific; nor were Nur77 or NOR1 induced before apoptosis under these circumstances. Gene expression of the NR4A nuclear receptor family and subsequent eosinophil apoptosis were downregulated by a MAPK inhibitor, but not by a p38 inhibitor. ERK1/2 phosphorylation by MEK1/2 downstream of CD30 signaling and upstream of the nuclear receptor family may be involved in apoptosis, but we still have no information on events downstream of these nuclear receptors.

Human NOR1 transgenic (TG) mice, into which ten copies of the actin promoter-constructed NOR1 gene had been incorporated, showed drastic phenotype changes. The TG mice were small with a body weight approximately half that of wild-type mice, and their thymuses and spleens showed evidence of dramatic atrophy (Kagaya et al. 2005b). Furthermore, NOR1 may be a semi-lethal gene, because the live birth ratio of the transgenic mice was less than $50 \%$. In addition, spleen cells of the TG mice were susceptible to apoptotic stimuli in culture. Though the precise regulatory mechanism is unknown, over-expression of NR4A nuclear receptors appears to regulate the downstream 
event following NR4A expression and induce cell death. Besides regulation of expression, it is speculated that their functions could be regulated through unknown endogenous agonists or synthetic low molecular weight compounds which directly bind their ligandbinding domains (LBDs).

\section{Transactivation of NR4A nuclear receptors and induction of apoptosis}

NR4A orphan nuclear receptors may not be genuinely orphan in nature, and an endogenous ligand may exist close to where these receptors are highly expressed. Such a hypothesis has been confirmed for chenodeoxycholic acid, which has been identified as an FXR ligand in liver, a region where the NR1H family member FXR is highly expressed (Makishima et al. 1999; Parks et al. 1999). Thus lipid mediators such as arachidonate and glycerolipid cascade metabolites, possibly induced in activated leukocytes following pathological stimuli, were screened. For screening, a mammalian hybrid system in which GAL4-NR4A receptor-linked chimera plasmids and the GAL4 binding domain-firefly luciferase reporter plasmid were cotransfected into cultured cells was used, and luciferase activity after ligand candidate addition was assayed. Only prostaglandin (PG) $A_{2}$ was found to have NR4A nuclear receptor-dependent transactivation activity in this system (Kagaya et al. 2005b).

$\mathrm{PGA}_{2}(3-10 \mu \mathrm{M})$ acted as a potent activator of NOR1 transcription through the GAL4-based reporter system, and LBD-deleted receptor showed little transcriptional activation by $\mathrm{PGA}_{2}$. The putative LBD of receptor was also proved to directly bind $\mathrm{PGA}_{2}$ using high-resolution Biacore S51. Evaluation of the effects of $\mathrm{PGA}_{2}$-like cyclopentenone derivatives on NR4Adependent transcription demonstrated that there are subtype-specific transactivators and clear structureactivity relationships, as assessed by minor modification of the functional groups in these very similar PG structures. A recent report using X-ray crystallographic analysis of the Nurr1 LBD demonstrated that it lacked a binding site for low molecular weight ligands (Wang et al. 2003). Although no information is currently available on the NOR1 LBD structure, NOR1 may lack a typical binding site conserved among steroid receptors, because the amino acid sequences are similar to the Nurr1 LBD. The evidence that the N-terminal AF-1 domain-deleted construct of NOR1 lost transcriptional activation by $\mathrm{PGA}_{2}$ suggests that the effects of $\mathrm{PGA}_{2}$ may require both the LBD and AF-1 domains of NOR1. Wansa et al. (2002, 2003) also demonstrated that the NR4A N-terminal AF-1 domain supports efficient recruitment of the co-activator complex necessary for transcriptional activity. Furthermore, the AF-1 domain was shown to interact directly with the C-terminal LBD domain (Maira et al. 2003). The above reports suggest an alternative explanation: that $\mathrm{PGA}_{2}$ transactivates NOR1 through AF-1-dependent co-activator recruitment and crosstalk between the AF-1 and LBD domains.

There is still no direct evidence as to whether exogenous $\mathrm{PGA}_{2}$ or its derivatives induce apoptosis in NOR1-expressing eosinophils. However, when $\mathrm{PGA}_{2}$ induced cell death in NOR1 TG mice was examined, it was surprisingly found that $\mathrm{PGA}_{2}$ showed strong effects on cell viability in spleen cells derived from these mice. This effect of $\mathrm{PGA}_{2}$ observed in the NOR1 TG mice was significantly greater than that in wild-type mice. These findings suggest a specific molecular linkage between $\mathrm{PGA}_{2}$ and NOR1, and in turn suggest possible therapeutic targets for the discovery of important new pharmacological agents. A scheme for the discovery of such anti-allergic agents is shown in Fig. 1.

Cyclopentenone $\mathrm{PG}$ derivatives including $\mathrm{PGA}_{2}$ have diverse pharmacological activities and manifest expected quantitative structure-activity relationships with respect to stimulation of neurite outgrowth (Satoh et al. 1999), antiviral function (Santoro 1997), and anticancer activity (Fukushima 1992). However, research in these areas is no longer topical because of the lack of success in identifying molecular targets to date. It has also been reported that $\mathrm{PGA}_{2}$ has apoptotic activity in some cells, though the definitive signaling cascade has not yet been elucidated. Previous reports have shown that $\mathrm{PGA}_{2}$ induces $\mathrm{p} 21^{\mathrm{Cip} 1}$ expression, suppresses cyclin D1 expression, and induces G1 arrest in proliferating cells (Hitomi et al. 1998; Tanikawa et al. 1998; Lin et al. 2000). Observations that the effects of $\mathrm{PGA}_{2}$ (induction of $\mathrm{p} 21^{\mathrm{Cip} 1}$, suppression of cyclin D1, and induction of cell death) were enhanced in spleen cells derived from NOR1 TG mice suggest that the effects of $\mathrm{PGA}_{2}$ are influenced, at least in part, by the expression levels of NOR1.

\section{Strategies used to develop anti-allergic drugs active at NR4A nuclear receptors}

The discovery of the existence of low molecular transactivators for these nuclear receptors and quantitative structure-activity relationships suggest that it will be possible to develop anti-allergic drugs by designing and screening agonists for these receptors. 


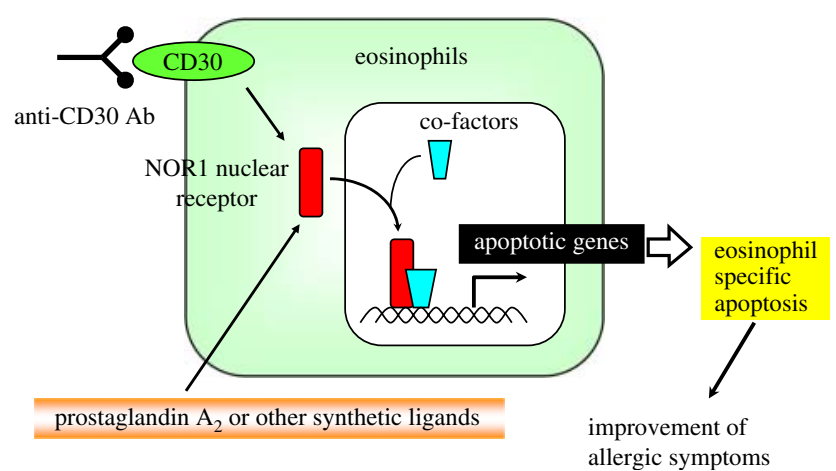

Fig. 1 Working hypotheses for eosinophil-specific apoptosis through the NOR1 nuclear receptor. Our findings suggest a specific molecular linkage between $\mathrm{PGA}_{2}$ and NOR1, and also suggest possible therapeutic targets for the discovery of important new pharmacological agents through the modulation of eosinophil apoptosis

NOR1 is the most promising target among NR4A receptors because it is eosinophil-specific. The strategy of specifically attacking and removing eosinophils was first attempted using an anti-IL-5 monoclonal antibody. Treatment with the antibody drastically reduced the numbers of circulating and sputum eosinophils, but did not improve airway responses in asthma patients (Leckie et al. 2000). These studies provoked a scientific controversy regarding the importance of eosinophils in the development of asthma. On the other hand, a recent study has proved that a significant number of eosinophils exist in the bronchial mucosa in asthmatic patients treated with anti-IL-5 antibody (Flood-Page et al. 2002). In support of these findings, Liu et al. (2002) have also reported the loss of IL- 5 receptor $\alpha$ on airway eosinophils after allergen challenge, which may explain the ineffectiveness of anti-IL-5 antibody. If eosinophil deletion could be achieved by treatment with low molecular weight chemicals, which might penetrate more easily into peripheral inflammatory tissues, the significance of the role of eosinophils would be established, and the controversy would be resolved. Recent reports in mutant eosinophil-deleted mice established that these mice did not exhibit signs of airway remodeling, even after continuous antigen challenge (Lee et al. 2004; Humbles et al. 2004). Airway remodeling in asthma involves well-defined chronic structural airway changes, including glandular increases within the airways, enhanced collagen deposition within the lamina propria, and an increase in the airway vasculature in conjunction with airway smooth muscle hypertrophy and hyperplasia (Holgate 2002; Homer and Elias 2005; Pascual and Peters 2005). While the above pathology is characteristic of asthma, diagnostic approaches to airway remodeling are now developing, for example using high-resolution CT scanning (Jaffuel et al. 2001). The strategy of provoking eosinophil-specific apoptosis may be effective when targeting airway remodeling in asthma, and may therefore become a novel treatment for chronic asthma.

These approaches might be applied not only to asthma but also to nasal polyps accompanied by allergic asthma and to atopic dermatitis, in which the roles of eosinophils are less clear than in the pathology of asthma. In fact, we have preliminary data that surgically removed nasal polyps containing large eosinophil accumulations expressed more than 100-fold higher amounts of NOR1 compared with other sections. On the other hand, Genox Research Inc. have also generated an expression profile database of lesional skin biopsy samples compared with non-lesional skin from more than ten AD patients (Ito et al. 2004; Ogawa et al. 2005). NOR1 was dominantly expressed in these lesional skin samples. Though the role of eosinophil infiltration in AD skin lesions is not sufficiently elucidated, it is worthy of further study.

The most recent successful milestones in molecular biological nuclear receptor pharmacology relate to our understanding of PPAR $\gamma$ function and the discovery of thiazolidine derivatives as antidiabetic agents for the treatment of non-insulin-dependent diabetes mellitus (NIDDM). There are some counter arguments about the role of 15-deoxy delta ${ }^{12,14} \mathrm{PGJ}_{2}$ as an endogenous ligand of PPAR $\gamma$ (Bell-Parikh et al. 2003). However, the finding that $\mathrm{PGA}_{2}$, another cyclopentenone-type PG pathway metabolite (whose receptor is not clearly defined), caused transactivation of the NOR1 receptor is most persuasive. The molecular target of anti-NIDDM thiazolidine derivatives was identified only after development of this drug class. Thus, it represents a significant challenge to identify a non-PG type NOR1 transactivator using pharmacophore information, virtual screening technology, and high-throughput screening, and to develop such compounds as antiallergic drugs via the drug development schemes outlined in Fig. 2.

At the present time, we can only offer the hypothesis that $\mathrm{PGA}_{2}$ localizes in high concentrations in leukocytes such as the eosinophil and acts as a true endogenous ligand of the NR4A nuclear receptor in these cells. This is because we have no information regarding actual concentrations of this substance in activated leukocytes. A fixed proportion of adult asthma cases are induced by nonsteroidal anti-inflammatory drugs (NSAIDs), and it is not known why NSAIDs have this action. We now know that the lipoxygenase pathway becomes dominant and leukotriene 


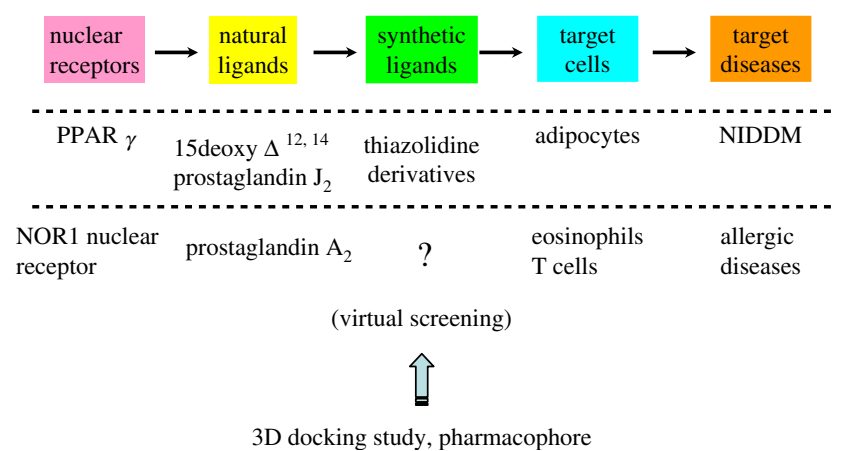

Fig. 2 Strategies for drug discovery through nuclear receptor research. This scheme shows the significant challenge involved in identifying a non-PG type NOR1 transactivator using pharmacophore information, virtual screening technology, and high-throughput screening, and in developing low molecular compounds as anti-allergic drugs, reproducing the success of thiazolidinediones as anti-NIDDM drugs

production is increased in inflammatory cells by NSAIDs which suppress the PG pathway during arachidonate metabolism (via cyclooxygenase inhibition), and this exacerbates asthmatic symptoms. However, is this theory really enough to explain the clinical phenomena? It is said that nasal polyps, which constitute an accumulation of eosinophils, are induced in a high percentage of aspirin-induced asthma cases. It may be that NSAIDs locally block production of the endogenous cyclopentenone-type PG in inflammatory cells; this leads to dysregulated eosinophil turnover in inflammatory sites through apoptosis, and significant accumulation of eosinophils takes the form of nasal polyps in inflammatory lesions. While the hypotheses outlined above are attractive, their application to the design of successful novel anti-allergic therapeutic strategies will provide proof of their veracity.

\section{Concluding remarks}

Nuclear receptors are among the most promising pharmacological target genes. Specific compounds that regulate NOR1-dependent transcriptional activity have the potential to be used as treatments for cancers and immunological disorders. By combining our information from gene suppression techniques, NOR1 may also be a promising target in the treatment of allergic diseases. Although the members of the NR4A family have been regarded as constitutive activators until now, new findings and hypotheses suggest that NR4A nuclear receptor pathways are subject to pharmacological modulation by low molecular weight compounds. Promising novel compounds active at
NOR1 nuclear receptors will inform future therapeutic strategies for NR4A-related human disorders.

Acknowledgments We are grateful to Drs. Masaji Ohno, Isao Tanaka, and Yukio Oya (Genox Research Inc.), Drs. Ken Yamaguchi and Toshihiko Tsukada (National Cancer Research Institute), Drs. Akira Akasawa, Toshio Katsunuma and Kenji Matsumoto (National Research Institute for Child Health and Development), and all members in Genox Research Inc. for their continuous encouragement.

\section{References}

Baumann MA, Paul CC (1998) The AML14 and AML14.3D10 cell lines: a long-overdue for the study of eosinophils and more. Stem Cells 16(1):1616-1624

Bell-Parikh LC, Ide T, Lawson JA, McNamara P, Reilly M, FitzGerald GA (2003) Biosynthesis of 15-deoxy-delta ${ }^{12,14}$ $\mathrm{PGJ}_{2}$ and the ligation of PPAR $\gamma$. J Clin Invest 112(6):945955

Bochner BS (2000) Systemic activation of basophils and eosinophils: markers and consequences. J Allergy Clin Immunol 106(Suppl 5):S292-S302

Chawla A, Repa JJ, Evans RM, Mangelsdorf DJ (2001) Nuclear receptors and lipid physiology: opening the X-files. Science 294(5548):1866-1870

Cheng LE, Chan FK, Cado D, Winoto A (1997) Functional redundancy of the Nur77 and Nor1 orphan steroid receptors in T-cell apoptosis. EMBO J 16(8):1865-1875

Eliashar R, Levi-Schaffer F (2005) The role of the eosinophil in nasal diseases. Curr Opin Otolaryngol Head Neck Surg 13(3):171-175

Fauman EB, Hopkins AL, Groom CR (2003) Structural bioinformatics in drug discovery. Methods Biochem Anal 44:477497

Flood-Page PT, Menzies-Gow AN, Kay AB, Robinson DS (2002) Anti-IL-5 (mepolizumab) only partially depletes eosinophils from asthmatic airway tissue. Am J Respir Crit Care Med 167(2):199-204

Forman BM, Tontonoz P, Chen J, Brun RP, Spiegelman BM, Evans RM (1995) 15-Deoxy-delta ${ }^{12,14}$-prostaglandin $J_{2}$ is a ligand for the adipocyte determination factor $\operatorname{PPAR} \gamma$. Cell 83(5):803-812

Fukushima M (1992) Biological activities and mechanisms of action of $\mathrm{PGJ}_{2}$ and related compounds: an update. Prostaglandins Leukot Essent Fatty Acids 47(1):1-12

Gefand EW (2004) Inflammatory mediators in allergic rhinitis. J Allergy Clin Immunol 114(Suppl 5):S135-S138

Gleich GJ (2000) Mechanisms of eosinophil-associated inflammation. J Allergy Clin Immunol 105(4):651-663

Granucci F, Castagnoli PR, Rogge L, Sinigaglia F (2001) Gene expression profiling in immune cells using microarray. Int Arch Allergy Immunol 126(4):257-266

Hashida R, Ogawa K, Miyagawa M, Sugita Y, Takahashi E, Nagasu T, Katsunuma T, Akasawa A, Tsujimoto G, Matsumoto K, Saito H (2003) Analysis of gene expression in peripheral blood eosinophils from patients with atopic dermatitis by differential display. Int Arch Allergy Immunol 131(Suppl 1):26-33

He YW (2002) Orphan nuclear receptors in $\mathrm{T}$ lymphocyte development. J Leukoc Biol 72(3):440-446

Heishi M, Kagaya S, Katsunuma T, Nakajima T, Yuki K, Akasawa A, Maeda M, Gunji S, Sugita Y, Tsujimoto G, 
Saito H (2002) High-density oligonucleotide array analysis of mRNA transcripts in peripheral blood cells of severe atopic dermatitis patients. Int Arch Allergy Immunol 129(1):57-66

Hitomi M, Shu J, Agarwal M, Agarwal A, Stacey DW (1998) p $21^{\text {Waf1 }}$ inhibits the activity of cyclin dependent kinase 2 by preventing its activating phosphorylation. Oncogene 17(8):959-969

Holgate ST (2002) Airway inflammation and remodeling in asthma: current concepts. Mol Biotechnol 22(2):179-189

Holt PG, Macaubas C, Stumbles PA, Sly PD (1999) The role of allergy in the development of asthma. Nature 402(Suppl):B12-B17

Homer RJ, Elias JA (2005) Airway remodeling in asthma: therapeutic implications of mechanisms. Physiology 20(20):28-35

Humbles AA, Lloyd CM, McMillan SJ, Friend DS, Xanthou G, McKenna EE, Ghiran S, Gerard NP, Yu C, Orkin SH, Gerard C (2004) A critical role for eosinophils in allergic airways remodeling. Science 305(5691):1776-1779

Imai Y, Nakada A, Hashida R, Sugita Y, Tanaka T, Tsujimoto G, Matsumoto K, Akasawa A, Saito H, Oshida T (2002) Cloning and characterization of the highly expressed ETEA gene from blood cells of atopic dermatitis patients. Biochem Biophys Res Commun 297(5):1282-1290

Ito T, Kito K, Adati N, Mitsui Y, Hagiwara H, Sakari Y (1994) Fluorescent differential display: arbitrary primed RT-PCR fingerprinting on an automatic DNA sequencer. FEBS Lett 351(2):231-236

Ito M, Ogawa K, Takeuchi K, Nakada A, Heishi M, Suto H, Mitsuishi K, Sugita Y, Ogawa H, Ra C (2004) Gene expression of enzymes for tryptophan degradation pathway is upregulated in the skin lesions of patients with atopic dermatitis of psoriasis. J Dermatol Sci 36(3):157-164

Jaffuel D, Paganin FJ, Bousquet J (2001) How can we assess airway remodeling using imaging? In: Howarth $\mathrm{PH}$, Wilson JW, Bousquet J, Rak S, Pauwels RA (eds) Airway remodeling. Marcel Dekker, New York, pp 5-25

Kafert S, Krauter J, Ganser A, Eder M (1999) Differential quantitation of alternatively spliced messenger RNAs using isoform-specific real-time RT-PCR. Anal Biochem 269(1):210-213

Kagaya S, Hashida R, Ohkura N, Tsukada T, Sugita Y, Terakawa M, Tsujimoto G, Katsunuma T, Akasawa A, Matsumoto K, Saito H (2005a) NR4A orphan nuclear receptor family in peripheral blood eosinophils from patients with atopic dermatitis and apoptotic eosinophils in vitro. Int Arch Allergy Immunol 137(Suppl 1):35-44

Kagaya S, Ohkura N, Tsukada T, Miyagawa M, Sugita Y, Tsujimoto G, Matsumoto K, Saito H, Hashida R (2005b) Prostaglandin $\mathrm{A}_{2}$ acts as a transactivator for NOR1 (NR4A3) within the nuclear receptor superfamily. Biol Pharm Bull 28(9):1603-1607

Kapp A (1993) The role of eosinophils in the pathogenesis of atopic dermatitis-eosinophil granule proteins as markers of disease activity. Allergy 48(1):1-5

Kim JH, Auerbach JM, Rodriguez-Gomez JA, Velasco I, Gavin D, Lumelsky N, Lee SH, Nguyen J, Sanchez-Pernaute R, Bankiewicz K, McKay R (2002) Dopamine neurons derived from embryonic stem cells function in an animal model of Parkinson's disease. Nature 418(6893):50-56

Kliewer SA, Lenhard LM, Willson TM, Patel I, Morris DC, Lehmann JM (1995) A prostaglandin $\mathrm{J}_{2}$ metabolite binds peroxisome proliferators-activated gamma and promotes adipocyte differentiation. Cell 83(5):813-819
Kliewer SA, Lehmann JM, Willson TM (1999) Orphan nuclear receptors: shifting endocrinology into reverse. Science 284(5415):757-760

Leckie MJ, ten Brinke A, Khan J, Diamant Z, O'Connor BJ, Walls CM, Mathur AK, Cowley HC, Chung KF, Djukanovic R, Hansel TT, Holgate ST, Sterk PJ, Barnes PJ (2000) Effects of an interleukin-5 blocking monoclonal antibody on eosinophils, airway hyper-responsiveness, and the late asthmatic response. Lancet 356(9248):2144-2148

Lee JJ, Dimina D, Macias MP, Ochkur SI, McGarry MP, O'Neill KR, Protheroe C, Pero R, Nguyen T, Cormier SA, Lenkiewicz E, Colbert D, Rinaldi L, Ackerman SJ, Irvin CG, Lee NA (2004) Defining a link with asthma in mice congenitally deficient in eosinophils. Science 305(5691):1773-1776

Leiferman KM (1994) Eosinophils in atopic dermatitis. J Allergy Clin Immunol 94(6):1310-1317

Liang P, Pardee AB (1992) Differential display of eukaryotic messenger RNA by means of the polymerase chain reaction. Science 257(5072):967-971

Lie YS, Petropoulos CJ (1998) Advances in quantitative PCR technology: 5'-nuclease assays. Curr Opin Biotechnol 9(1):43-48

Lin S, Wang W, Wilson GM, Yang X, Brewer G, Holbrook NJ, Gorospe M (2000) Down-regulation of cyclin D1 expression by prostaglandin $\mathrm{A}_{(2)}$ is mediated by enhanced cyclin D1 mRNA turnover. Mol Cell Biol 20(21):7903-7913

Liu LY, Sedgwick JB, Bates ME, Vrtis RF, Gern JE, Kita H, Jarjour NN, Busse WW, Kelly EA (2002) Decreased expression of membrane IL-5 receptor alpha on human eosinophils: I. Loss of membrane IL-5 receptor alpha on airway eosinophils and increased soluble IL-5 receptor alpha in the airway after allergen challenge. J Immunol 169(11):6452-6458

Maglich JM, Sluder A, Guan X, Shi Y, McKee DD, Carrick K, Kamdar K, Willson TM, Moore JT (2001) Comparison of complete nuclear receptor sets from the human, Caenorhabditis elegans and Drosophila genomes. Genome Biol 2(8):1-7

Maira M, Martens C, Philips A, Drouin J (1999) Heterodimerization between members of the Nur subfamily of orphan nuclear receptors as a novel mechanism for gene activation. Mol Cell Biol 19(11):7549-7557

Maira M, Martens C, Batsche E, Gauthier Y, Drouin J (2003) Dimer-specific potentiation of NGFI-B (Nur77) transcriptional activity by the protein kinase A pathway and AF-1dependent coactivator recruitment. Mol Cell Biol 23(3):763776

Makishima M, Okamoto AY, Repa JJ, Tu H, Learned RM, Luk A, Hull MV, Lustig KD, Mangelsdorf DJ, Shan B (1999) Identification of a nuclear receptor for bile acids. Science 284(5418):1362-1365

Matsumoto Y, Oshida T, Obayashi I, Imai Y, Matsui K, Yoshida NL, Nagata N, Ogawa K, Obayashi M, Kashiwabara T, Gunji S, Nagasu T, Sugita Y, Tanaka T, Tsujimoto G, Katsunuma T, Akasawa A, Saito H (2002) Identification of highly expressed genes in peripheral blood $\mathrm{T}$ cells from patients with atopic dermatitis. Int Arch Allergy Immunol 129(4):327-340

Matsumoto Y, Imai Y, Yoshida NL, Sugita Y, Tanaka T, Tsujimoto G, Saito H, Oshida T (2004a) Upregulation of the transcript level of GTPase activating protein KIAA0603 in $\mathrm{T}$ cells from patients with atopic dermatitis. FEBS Lett 572(1-3):135-140

Matsumoto K, Terakawa M, Miura K, Fukuda S, Nakajima S, Saito H (2004b) Extremely rapid and intense induction of 
apoptosis in human eosinophils by anti-CD30 antibody treatment in vitro. J Immunol 172(4):2186-2193

Nagata N, Oshida T, Yoshida NL, Yuyama N, Sugita Y, Tsujimoto G, Katsunuma T, Akasawa A, Saito H (2003) Analysis of highly expressed genes in monocytes from atopic dermatitis patients. Int Arch Allergy Immunol 132(2):156167

Ogawa K, Hashida R, Miyagawa M, Kagaya S, Sugita Y, Matsumoto K, Katsunuma T, Akasawa A, Tsujimoto G, Saito H (2003) Analysis of gene expression in peripheral blood eosinophils from patients with atopic dermatitis and in vitro cytokine-stimulated blood eosinophils. Clin Exp Immunol 131(3):436-445

Ogawa K, Ito M, Miyagawa M, Nagasu T, Sugita Y, Katsunuma $\mathrm{T}$, Akasawa A, Matsumoto $\mathrm{K}$, Tsujimoto $\mathrm{G}$, Saito $\mathrm{H}$, Hashida R (2004) Expression of a human SOCS protein, HSOCP-1, in peripheral blood eosinophils from patients with atopic dermatitis. Int Arch Allergy Immunol 134(Suppl 1):2-6

Ogawa K, Ito M, Takeuchi K, Nakada A, Heishi M, Suto H, Mitsuishi K, Sugita Y, Ogawa H, Ra C (2005) Tenascin-C is upregulated in the skin lesions of patients with atopic dermatitis. J Dermatol Sci 40(1):35-41

Parks DJ, Blanchard SG, Bledsoe RK, Chandra G, Consler TG, Kliewer SA, Stimmel JB, Willson TM, Zavacki AM, Moore DD, Lehmann JM (1999) Bile acids: natural ligands for an orphan nuclear receptor. Science 284(5418):1365-1368

Pascual RM, Peters SP (2005) Airway remodeling contributes to the progressive loss of lung function in asthma: an overview. J Allergy Clin Immunol 116(3):477-486

Perlmann T, Jansson L (1995) A novel pathway for vitamin A signaling mediated by RXR heterodimerization with NGFIB and NURR1. Genes Dev 9(7):769-782

Saito H, Bourinbaiar A, Ginsburg M, Minato K, Ceresi E, Yamada K, Machover D, Breard J, Mathe G (1985) Establishment and characterization of a new human eosinophilic leukemia cell line. Blood 66(6):1233-1240

Santoro MG (1997) Antiviral activity of cyclopentenone prostanoids. Trends Microbiol 5(7):276-281

Satoh T, Furuta K, Suzuki M, Watanabe Y (1999) Prostaglandin $\mathrm{J}_{2}$ and its metabolites promote neurite outgrowth induced by nerve growth factor PC12 cells. Biochem Biophys Res Commun 258(1):50-53

Saucedo-Cardenas O, Quintana-Hau JD, Le WD, Smidt MP, Cox JJ, De Mayo F, Burbach JP, Conneely OM (1998) Nurr1 is essential for the induction of the dopaminergic phenotype and the survival of ventral mesencephalic late dopaminergic precursor neurons. Proc Natl Acad Sci USA 95(7):4013-4018
Schmidt-Weber CB, Wohlfahrt JG, Blaser K (2001) DNA assays in allergy and immunology. Int Arch Allergy Immunol 126(1):1-10

Steff AM, Trop S, Maira M, Drouin J, Hugo P (2001) Opposite ability of pre-TCR and alpha beta TCR to induce apoptosis. J Immunol 166(8):5044-5050

Takeda K, Ichiki T, Tokunou T, Iino N, Takeshita A (2001) 15Deoxy-delta ${ }^{12,14}$-prostaglandin $\mathrm{J}_{2}$ and thiazolidinediones activate the MEK/ERK pathway through phosphatidylinositol 3-kinase in vascular smooth muscle cells. J Biol Chem 276(52):48950-48955

Tanikawa M, Yamada K, Tominaga K, Morisaki H, Kaneko Y, Ikeda K, Suzuki M, Kiho T, Tomokiyo K, Furuta K, Noyori R, Nakanishi M (1998) Potent prostaglandin $A_{1}$ analogs that suppress tumor cell growth through induction of p21 and reduction of cyclin E. J Biol Chem 273(29):522-527

Ueki S, Adachi T, Bourdeaux J, Oyamada H, Yamada Y, Hamada K, Kanda A, Kayaba H, Chihara J (2003) Expression of PPAR $\gamma$ in eosinophils and its functional role in survival and chemotaxis. Immunol Lett 86(2):183-189

Vivat V, Zechel C, Wurtz JM, Bourguet W, Kagechika H, Umemiya H, Shudo K, Moras D, Gronemeyer H, Chambon P (1997) A mutation mimicking ligand-induced conformational change yields a constitutive RXR that senses allosteric effects in heterodimers. EMBO J 16(18):5697-5709

Wang Z, Benoit G, Liu J, Prasad S, Aarnisalo P, Liu X, Xu H, Walker NP, Perlmann T (2003) Structure and function of Nurr1 identifies a class of ligand-independent nuclear receptors. Nature 423(6939):555-560

Wansa KD, Harris JM, Muscat GE (2002) The activation function-1 domain of Nur77/NR4A1 mediates trans-activation, cell specificity, and coactivator recruitment. J Biol Chem 277(36):33001-33011

Wansa KD, Harris JM, Yan G, Ordentlich P, Muscat GE (2003) The AF-1 domain of orphan nuclear receptor NOR-1 mediates trans-activation, coactivator recruitment, and activation by the purine anti-metabolite 6-mercaptopurine. J Biol Chem 278(27):24776-24790

Winoto A, Littman DR (2002) Nuclear hormone receptors in T lymphocytes. Cell 109(Suppl):S57-S66

Zetterstrom RH, Solomin L, Mitsiadis T, Olson L, Perlmann T (1996a) Retinoid X receptor heterodimerization and developmental expression distinguish the orphan nuclear receptors NGFI-B, Nurr1, and Nor1. Mol Endocrinol 10(12):1656-1666

Zetterstrom RH, Williams R, Perlmann T, Olson L (1996b) Cellular expression of the immediate early transcription factors Nurr1 and NGFI-B suggests a gene regulatory role in several brain regions including the nigrostriatal dopamine system. Brain Res Mol Brain Res 41(1-2):111-120 